\title{
Anemia severity among children aged 6-59 months in Gondar town, Ethiopia: a community-based cross-sectional study
}

Mulugeta Melku1*0, Kefyalew Addis Alene ${ }^{2}$, Betelihem Terefe', Bamlaku Enawgaw', Belete Biadgo ${ }^{3}$, Molla Abebe $^{3}$, Kindie Fentahun Muchie ${ }^{2}$, Asemarie Kebede ${ }^{4}$, Tadele Melak ${ }^{3}$ and Tsedalu Melku ${ }^{5}$

\begin{abstract}
Background: Anemia is a public health problem affecting both developed and developing countries. Childhood anemia is associated with serious consequences including growth retardation, impaired motor and cognitive development, and increased morbidity and mortality. Hence, this study aimed at assessing the prevalence and factors associated with severity of anemia among children aged 6-59 months in Gondar town, northwest Ethiopia.

Method: A community-based cross-sectional study was conducted. A multi-stage sampling technique was employed to select study participants. Socio demographic and socioeconomic data were collected using a pre-tested structured questionnaire. Anthropometric measurements were taken as per WHO recommendation. Hemoglobin ( $\mathrm{Hb})$ concentration was measured using a portable HemoCue301 instrument (A Quest Diagnostic Company, Sweden). Mild anemia corresponds to a level of adjusted $\mathrm{Hb}$ of $10.0-10.9 \mathrm{~g} / \mathrm{dl}$; moderate anemia corresponds to a level of 7.0-9.9 g/ $\mathrm{dl}$, while severe anemia corresponds to a level less than $7.0 \mathrm{~g} / \mathrm{dl}$. Descriptive statistics were used to describe the study participants. Both bivariable and multivariable ordinal logistic regression were done, and proportional odds ratio (POR) with a 95\% confidence interval (Cl) was reported to show the strength of association. A $p$-value $<0.05$ was considered statistically significant.
\end{abstract}

Result: Out of the total of 707 children included in this study, more than half (53.5\%) of them were male. The median age of children was 30 months. Two hundred two (28.6\%) of children were anemic: 124(17.5\%) were mildly anemic, $73(10.3 \%)$ were moderately anemic, and $5(0.7 \%)$ were severely anemic. The young age of the child, low frequency of child complementary feeding per day, primary maternal educational status, unmarried maternal marital status, and home delivery were factors associated with severity of childhood anemia.

Conclusion: Anemia among children aged 6-59 months in Gondar Town was a moderate public health problem. Improving access to education, providing regular health education about childcare and child feeding practices, strengthening the socioeconomic support for single-parent families and conducting regular community-based screening are recommended to reduce childhood anemia.

Keywords: Anemia, Associated factors, Children, Severity

\footnotetext{
* Correspondence: mulugeta.melku@gmail.com

${ }^{1}$ Department of Hematology and Immunohematology, School of Biomedical and Laboratory Sciences, College of Medicine and Health Sciences, University of Gondar, Gondar, Ethiopia

Full list of author information is available at the end of the article
}

(c) The Author(s). 2018 Open Access This article is distributed under the terms of the Creative Commons Attribution 4.0 International License (http://creativecommons.org/licenses/by/4.0/), which permits unrestricted use, distribution, and reproduction in any medium, provided you give appropriate credit to the original author(s) and the source, provide a link to the Creative Commons license, and indicate if changes were made. The Creative Commons Public Domain Dedication waiver (http://creativecommons.org/publicdomain/zero/1.0/) applies to the data made available in this article, unless otherwise stated. 


\section{Background}

Anemia, defined as a low blood hemoglobin ( $\mathrm{Hb}$ ) concentration, is one of the most common and widespread disorders in the world, affecting one-quarter of the world's population. It is a major public health problem in several countries, particularly common among preschool-aged children and women [1]. According to the 2011 World Health Organization (WHO) report, anemia resulting from iron deficiency was one of the most important factors contributing to the global burden of diseases, and it increases morbidity and mortality in preschool-aged children and pregnant women [2]. Globally, anemia affects 1.62 billion people, which correspond to $24.8 \%$ of the population. The highest prevalence is found in preschool-age children (47.4\%). WHO regional estimate indicated that the highest proportion of anemic preschool-age children are residing in Africa [2, 3]. Anemia is also a major public health problem among preschool-aged children in Ethiopia [4].

Childhood anemia has a substantial association with social, economic, psychological, and health-related problems. The evidence demonstrated that early childhood anemia is a strong predictor of adulthood anemia [4]. A considerable number of studies reported that childhood iron deficiency anemia has been strongly correlated with psychiatric disorders, mental retardation and developmental disorders [5-8]. Anemia dysfunctions recent and past memory concentration domain of the children. Children with anemia have a lower developmental index, poor motor development, no interest in their environment, a shorter attention span, diminished cognitive ability and behavioural problems [9]. As a result, anemia at early childhood continues to affect school achievement and behavioural development negatively $[10,11]$. In addition, childhood anemia is a common condition causing significant morbidity and mortality. Severe anemia carries a high 'hidden' morbidity and mortality occurring months after initial diagnosis and treatment, and it is the common contributing factor for overall under-five mortality [12].

The etiology of anemia is often multi-factorial and interrelated in a complex way. In developing countries, micronutrient deficiency and infectious diseases take the greatest part [13-17]. Socio-economic status, demographic characteristics, child feeding practices, accessibility for preventive and curative health services have also been playing a major role [18-20]. Maternal anemia during pregnancy may also be associated with the development of childhood anemia $[21,22]$. Besides, genetic factors like hemoglobinopathies are the cause of anemia [14, 23].

Anemia prevalence data remains to be an important indicator of public health since anemia is related to morbidity and mortality, particularly in a most vulnerable segment of the population such as preschool-aged children and pregnant women [22]. In order to make a full use of these prevalence data, information on factors associated with anemia should be collected so that interventions can be better adapted to the local situation and can, therefore, be more effective. However, much is not known about the prevalence and associated factors of childhood anemia severity in Ethiopia. Thus, the aim of this study was to assess the prevalence and factors associated with severity of anemia among children aged 659 months in Gondar town, northwest Ethiopia.

\section{Methods}

Study design, population, and sampling technique

A community-based cross-sectional study was conducted in April 2015 among children aged 6-59 months in Gondar town, northwest Ethiopia. A sample size of 735 was calculated by single population proportion formula, considering estimated prevalence of anemia (35.1\%) among children aged 6-59 month in Amhara region [4], 95\%CI, $5 \%$ margin of error, design effect of 2 , and $5 \%$ non- response rate. A multi-stage random sampling technique was employed to select study participants in two stages. At the first stage, four out of twelve kebeles (smallest administrative units) (i.e. $30 \%$ of the total area) were selected by simple random sampling technique. At the second stage, a total of 735 households were selected using a systematic random sampling method with proportional allocation to each selected kebeles. The total number of households with children aged between 6 and 59 months was obtained from the respective administrative areas and used to calculate the sampling fraction. In the case where more than one children were found eligible in the selected households, only one of them was chosen randomly using the lottery method.

\section{Data collection methods and instruments}

A pretested structured questionnaire was used to collect socio-demographic and economic data from mothers by face-to-face interview. Anthropometric measurements such as weight and height were measured for children according to the $2006 \mathrm{WHO}$ recommendation [24]. Z-scores for weight-for-age (WAZ), height-for-age (HAZ), and weight-for-height (WHZ) were calculated using WHO Anthro software. Nutritional status was defined as underweight if WAZ was less than - 2 standards deviation (SD), stunting if HAZ was less than -2SD, and wasting if WHZ was less than -2SD [25]. Body mass index (BMI) was also calculated for the mothers according to the WHO STEP-wise surveillance manual [26].

$\mathrm{Hb}$ was measured by a portable HemoCue301 instrument (A Quest Diagnostic Company, Sweden) from capillary blood. HemoCue method of $\mathrm{Hb}$ determination is recommended by WHO to determine population prevalence of anemia, and several studies have established the validity of this instrument [24, 27]. After adjusting $\mathrm{Hb}$ concentration for altitude, anemia was defined as mild if 
$\mathrm{Hb}$ was between 10 and $10.9 \mathrm{mg} / \mathrm{dl}$, moderate if between 9.9 and $7 \mathrm{~g} / \mathrm{dl}$, and severe if $<7 \mathrm{~g} / \mathrm{dl}[24]$.

\section{Data quality assurance}

The questionnaire was prepared in English, translated to Amharic and then translated back to English to check for consistency. Data were collected by trained data collectors (BSC nurses and senior medical laboratory technologists) after training was given about the objective of the study, confidentiality issues, study participants' right, consenting, techniques of interview, and $\mathrm{Hb}$ and anthropometric measurements. The data collection process was closely supervised by investigators. All measurements were performed by following the manufacturers' recommendation.

\section{Data management and analysis}

Data were entered using Epi Info version 3.5.3 statistical software, and then exported to SPSS version 20 for analysis. Descriptive statistics including frequencies, percentages, median, and interquartile range were performed to describe the study participants. The bi-variable and multi-variable proportional odds model (POM), the most widely used family of ordinal logistic regression in epidemiological studies, was fitted to identify factors associated with severity of childhood anemia. The proportionality assumptions for POM were checked using Chi-square parallel line tests, $(p$-value $=0.791)$ indicating that the assumption was not violated. The Pearson chi-square goodness-of-fit test showed that the model fitted the data well $(p=0.152)$. All variables with a $p$-value $\leq 0.2$ in the bivariable analysis were fitted into the multivariable analysis to control confounding effects. Adjusted proportional odds ratio (aPOR) with a 95\% $\mathrm{CI}$ was used to evaluate the strength of statistical association between explanatory and outcome variables. All variables with $p$-values $<0.05$ in the multi-variable analysis were considered to be statistically significant.

\section{Result}

\section{Characteristics of study participants}

A total of 735 children were selected; of whom 707 participated in the study, with a response rate of $96.2 \%$. More than half, 378 (53.5\%), of the children were male. The median age of children was 30 months (interquartile range $(\mathrm{IQR})=24$ months). From the total children, 323 $(45.7 \%)$ were stunted, $562(79.5 \%)$ were delivered at health institutions, and 577(81.6\%) had been exclusively breastfed for 6 months (Table 1).

\section{Parental characteristics}

Concerning the maternal characteristics, $619(87.6 \%)$ were married, 500(70.7\%) were housewives, $472(66.8 \%)$ had a normal weight, and 364(51.5\%) were 25-30 years old. About 287(40.6\%) of children's fathers were governmental or private sector employees, and 237(33.5\%) attended primary education. More than half, 376(53.2\%), of children were living in a family with a monthly income of 60-124 US dollar (\$). Moreover, 143(20.2\%) of the children were living in a family with more than five members, and $142(20.1 \%)$ were living in a family with two or more under five-year-old children (Table 2).

\section{Prevalence of anemia}

The overall prevalence of anemia among children aged 6-59 months was 202 (28.6\%) (95\% CI: 25.2-31.9\%). The prevalence of mild, moderate, and severe anemia were $124(17.5 \%), 73(10.3 \%)$, and $5(0.7 \%)$, respectively. The highest prevalence of anemia $(46.8 \%)$ was found in children whose mothers did not receive antenatal care (ANC) during pregnancy period of sampled children. Regarding the severity, the highest prevalence of severe anemia (6.7\%) was found in twin children. About $24.3 \%$, $21.6 \%$ and $2.7 \%$ of children aged 6-11 months were mildly, moderately and severely anemic, respectively. Out of the total children being breastfed during the data collection, $1.3 \%, 15.9 \%$ and $23.6 \%$ of them were severely, moderately and mildly anemia, respectively (Table 3 ).

\section{Factors associated with anemia}

In the bivariable POM, age of child, maternal age, maternal educational status, maternal marital status, ANC visit at that time of pregnancy, child's place of birth(home delivery), frequency of complementary feeding per day, loss of appetite, presence of morbidity symptoms (fever, vomiting, fast breathing and cough), breastfeeding status at the time of survey, and family monthly income were associated with anemia severity. However, in multivariable POM, being a young aged child (5-11 months [aPOR $=13.9,95 \%$ CI: $3.50-35.02$ ], $12-23$ months [aPOR $=8.53$, 95\%CI: $3.8-19.18], 24-35$ months $[\mathrm{aPOR}=4.77$, 95\%CL: $1.67-10.04$ ], 36-47 months [aPOR $=3.58,95 \%$ : $1.67-7.65]$ ), being child of a mother with a primary educational status $[\mathrm{aPOR}=1.71,95 \% \mathrm{CI}: 1.10-2.65]$, being a child delivered at home $[\mathrm{aPOR}=1.64,95 \% \mathrm{CI}$ : 1.03 2.61], being child of mother whose marital status was unmarried [aPOR $=1.8,95 \% \mathrm{CI}: 1.07-3.03$ ], and low frequency of complementary feeding practice per day [aPOR $=2.46,95 \% \mathrm{CI}: 1.02-5.77]$ were the factors associated with childhood anemia severity (Table 4 ).

\section{Discussion}

Anemia prevalence data remain to be an important indicator of public health since anemia is related to morbidity and mortality, particularly in more vulnerable -preschool aged children and pregnant women [22]. As per WHO and United Nations report on the progress of achieving Millennium development goals (MDG), even though substantial progress has been made towards achieving MDG4 
Table 1 Characteristics of children aged 6-59 months who participated in the study, Gondar Town, April 2014

\begin{tabular}{|c|c|c|c|}
\hline Characteristics & Categories & Frequency (n) & Percentage (\%) \\
\hline \multirow[t]{2}{*}{ Sex of child } & Male & 378 & 53.5 \\
\hline & Female & 329 & 46.5 \\
\hline \multirow[t]{5}{*}{ Age of child (months) } & $6-11$ & 74 & 10.5 \\
\hline & $12-23$ & 181 & 25.6 \\
\hline & $24-35$ & 174 & 24.6 \\
\hline & $36-47$ & 155 & 21.9 \\
\hline & $48-59$ & 123 & 17.4 \\
\hline \multirow[t]{2}{*}{ Child's place of delivery } & At home & 145 & 20.5 \\
\hline & At health institution & 562 & 79.5 \\
\hline \multirow[t]{2}{*}{ Child's birth type } & Singleton & 692 & 97.9 \\
\hline & Twins & 15 & 2.1 \\
\hline \multirow[t]{2}{*}{ Mode of delivery } & CS or instrumental delivery & 73 & 10.3 \\
\hline & spontaneous vaginal delivery & 634 & 89.7 \\
\hline \multirow[t]{2}{*}{ Pre-lacteal feeding } & Yes & 58 & 8.2 \\
\hline & No & 649 & 91.8 \\
\hline \multirow[t]{2}{*}{ Exclusive breastfeeding status ${ }^{a}$} & Exclusively breastfed & 577 & 81.6 \\
\hline & Not exclusively breastfed & 130 & 18.4 \\
\hline \multirow[t]{2}{*}{ Breastfeeding status } & Being breastfed & 301 & 42.6 \\
\hline & Not being breastfed & 406 & 57.4 \\
\hline \multirow[t]{3}{*}{ Preceding birth interval ${ }^{b}$} & 12-24 months & 83 & 19.9 \\
\hline & 25-48 months & 149 & 35.6 \\
\hline & $>48$ months & 186 & 44.5 \\
\hline \multirow[t]{2}{*}{$\mathrm{WHZ}$} & Wasted & 46 & 6.5 \\
\hline & Normal & 661 & 93.5 \\
\hline \multirow[t]{2}{*}{ HAZ } & Stunted & 323 & 45.7 \\
\hline & Normal & 384 & 54.3 \\
\hline \multirow[t]{2}{*}{ WAZ } & Underweight & 111 & 15.7 \\
\hline & Normal & 596 & 84.3 \\
\hline \multirow[t]{3}{*}{ Complementary feeding frequency } & $<4$ time per day & 210 & 29.7 \\
\hline & 4-5 times per day & 440 & 62.2 \\
\hline & $>5$ time per day & 57 & 8.1 \\
\hline
\end{tabular}

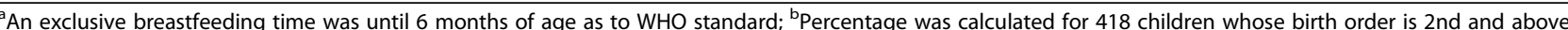
CS: Caesarian section; HAZ: Height-for-Age Z-score; WAZ: Weight-for-Age Z-score; WHZ: Weight-for-Height Z-score

to reduce the number of under-five mortality rate worldwide, the rate of decline remains insufficient to meet the stated goal, particularly in sub-Saharan Africa and southern Asia. By the year 2011, children born in sub-Saharan Africa faced a higher probability of dying before the age of five than children born elsewhere [28, 29]. This raises questions about the impact and effectiveness of interventions made to reduce the burden of anemia, since anemia prevalence is a useful indicator to assess the impact and effectiveness of interventions [22].

In this study, the overall prevalence of anemia among children aged 6-59 months was found to be $28.5 \%$. It is a moderate public health problem and should be addressed using appropriate intervention strategies since anemia contributes to childhood morbidity and mortality [24]. This prevalence is consistent with studies done in South-central Ethiopia [30], Timor-Leste [18], and Northeastern Brazil [31]. However, it is lower than studies conducted in another part of Ethiopia [32-34]. Tanzania [35], Benin and Mali [36], Haiti [37], Bangladesh [38], Indonesia [17], and Pernambuco, Northeastern Brazil [39]. In contrary to this, it is higher than studies conducted in Acrelandia, Western Brazilian Amazonia [19], and Vitoria, Brazilian [40]. The plausible reasons for disparities in anemia prevalence between the present study and aforementioned studies might be related to the seasonal and 
Table 2 Socio-demographic and economic characteristic of parents of children participated in the study, Gondar Town, April 2014

\begin{tabular}{|c|c|c|c|}
\hline Characteristics & Categories & Frequency (n) & Percentage (\%) \\
\hline \multirow[t]{4}{*}{ Maternal age(year) } & $<25$ & 165 & 23.3 \\
\hline & $25-30$ & 364 & 51.5 \\
\hline & $31-35$ & 102 & 14.4 \\
\hline & $>35$ & 76 & 10.7 \\
\hline \multirow[t]{2}{*}{ Maternal marital status } & Married & 619 & 87.6 \\
\hline & Unmarried $^{\mathrm{a}}$ & 88 & 12.4 \\
\hline \multirow[t]{4}{*}{ Maternal educational status } & No formal education & 220 & 31.1 \\
\hline & Primary education & 210 & 29.7 \\
\hline & Secondary education & 218 & 30.8 \\
\hline & Tertiary education & 59 & 8.9 \\
\hline \multirow[t]{4}{*}{ Maternal occupation } & Housewives & 500 & 70.7 \\
\hline & Government or private sector employees & 38 & 5.3 \\
\hline & Merchants & 58 & 8.2 \\
\hline & Daily laborer & 111 & 15.8 \\
\hline \multirow[t]{3}{*}{ Maternal BMI } & Underweight & 95 & 13.4 \\
\hline & Normal weight & 472 & 66.8 \\
\hline & Overweight & 140 & 19.8 \\
\hline \multirow[t]{4}{*}{ Paternal educational status } & No formal education & 163 & 23 \\
\hline & Primary education & 237 & 33.5 \\
\hline & Secondary education & 220 & 31.1 \\
\hline & Tertiary education & 87 & 12.3 \\
\hline \multirow[t]{3}{*}{ Paternal occupation } & Government or private sector employees & 287 & 40.6 \\
\hline & Merchants & 236 & 33.4 \\
\hline & Daily laborer & 184 & 26 \\
\hline \multirow[t]{3}{*}{ Family size } & $<4$ & 250 & 35.4 \\
\hline & $4-5$ & 314 & 44.4 \\
\hline & $>5$ & 143 & 20.2 \\
\hline \multirow[t]{2}{*}{ Number of under-five children } & 1 & 565 & 79.9 \\
\hline & $\geq 2$ & 142 & 20.1 \\
\hline \multirow[t]{3}{*}{ Family monthly income } & $<\$ 60$ & 162 & 22.9 \\
\hline & $\$ 60-124$ & 376 & 53.2 \\
\hline & $>\$ 124$ & 169 & 23.9 \\
\hline
\end{tabular}

includes single and widowed, 1USD is equivalent to 20.90 Ethiopian Birr based on the 2015 exchange rate; Unmarried ${ }^{\mathrm{a}}$ : includes Single, divorced and widowed; BMl: Body Mass Index

geographic variability of risk factors, and differences in socioeconomic status of the populations in which the studies were conducted.

In our study, the prevalence of mild anemia was higher than the other types of anemia. This result is consistent with previous studies conducted in Northern Ethiopia [33], Haiti [37], and Western China [41], in which mild anemia was reported as the most common type of anemia among children. This could be due to the fact that children with mild anemia are mostly asymptomatic, and they may not seek medical intervention and may not get treatment. The clinical symptoms may not be presented in children with mild anemia, as the body often compensates for the gradual changes in $\mathrm{Hb}$ concentration.. This indicates that anemia is a hidden public health problem that affects a significant number of children. The other possible reason could be due to the fact that almost half of the children in our study were stunted, where mild anemia is more common in stunted children.

In this study, younger aged children were more likely to be anemic. The likelihood of being anemic among children aged 6-11 months was higher as compared to those who were within the age of $48-59$ months. This is 
Table 3 The prevalence and severity of anemia according to selected children and parental characteristics

\begin{tabular}{|c|c|c|c|c|c|c|}
\hline \multirow[t]{2}{*}{ Variable } & \multirow[t]{2}{*}{ Categories } & \multicolumn{5}{|c|}{ Anemic status and severity level (n (\%)) } \\
\hline & & Severely anemic & Moderately anemic & Mildly anemic & Non-anemic & $\begin{array}{l}\text { Overall anemia } \\
\text { prevalence }\end{array}$ \\
\hline \multirow[t]{2}{*}{ Sex of child } & Male & $3(0.8)$ & $38(10.1)$ & $69(18.3)$ & $268(70.9)$ & $110(29.1)$ \\
\hline & Female & $2(0.6)$ & $35(10.6)$ & $55(16.8)$ & $237(72.0)$ & $92(28.0)$ \\
\hline \multirow[t]{5}{*}{ Age of child (months) } & $6-11$ & $2(2.7)$ & $16(21.6)$ & $18(24.3)$ & $38(51.4)$ & $36(48.6)$ \\
\hline & $12-23$ & $1(0.6)$ & $29(16.0)$ & $45(24.9)$ & $106(58.8)$ & $75(41.4)$ \\
\hline & $24-35$ & $1(0.6)$ & $19(10.9)$ & $27(15.5)$ & $127(73.0)$ & $47(27.0)$ \\
\hline & $36-47$ & $1(0.6)$ & $6(3.9)$ & $26(16.8)$ & $122(78.7)$ & $33(21.3)$ \\
\hline & $48-59$ & 0 & $3(2.4)$ & $8(6.5)$ & $112(91.1)$ & $11(8.9)$ \\
\hline \multirow[t]{2}{*}{ WHZ } & Wasted & 0 & $6(13.0)$ & $8(17.4)$ & $32(69.6)$ & $14(30.4)$ \\
\hline & Normal & $5(0.8)$ & $67(10.1)$ & $116(17.5)$ & $473(71.6)$ & $188(28.4)$ \\
\hline \multirow[t]{2}{*}{ HAZ } & Stunted & $3(0.9)$ & $30(9.3)$ & $60(18.6)$ & $230(71.2)$ & $93(28.8)$ \\
\hline & Normal & $2(0.5)$ & $43(11.2)$ & $64(16.7)$ & $275(71.6)$ & $109(28.4)$ \\
\hline \multirow[t]{2}{*}{ WAZ } & Underweight & $2(1.8)$ & $9(8.1)$ & $23(20.7)$ & $77(69.4)$ & $34(30.6)$ \\
\hline & Normal & $3(0.5)$ & $64(10.7)$ & $101(16.9)$ & $428(71.8)$ & $168(28.2)$ \\
\hline \multirow[t]{3}{*}{ Maternal age } & $<25$ years & $1(0.6)$ & $18(10.9)$ & $41(24.8)$ & 105 (63.6) & $60(36.4)$ \\
\hline & $25-35$ years & 0 & $7(9.2)$ & $13(17.1)$ & $56(73.7)$ & $20(26.3)$ \\
\hline & $>35$ years & $4(0.9)$ & $48(10.3)$ & $70(15.0)$ & $344(73.8)$ & $122(26.2)$ \\
\hline \multirow[t]{3}{*}{ Maternal education } & No formal education & $2(0.9)$ & $25(11.4)$ & $42(19.1)$ & $151(68.6)$ & 69 (31.4) \\
\hline & Primary education & 0 & $27(12.9)$ & $44(21.0)$ & $139(66.2)$ & $71(33.8)$ \\
\hline & Secondary and above & $3(1.1)$ & $21(7.6)$ & 38 (13.7) & $215(77.6)$ & $62(22.4)$ \\
\hline \multirow[t]{3}{*}{ Frequency of ANC visits } & Never visited & $1(2.1)$ & $9(9.1)$ & $12(25.5)$ & $25(53.2)$ & $22(46.8)$ \\
\hline & 1-4 times visited & $4(0.7)$ & $55(9.4)$ & $101(17.2)$ & $428(72.8)$ & $160(27.2)$ \\
\hline & More than 4 times visited & 0 & $9(12.5)$ & $11(15.3)$ & $52(72.2)$ & $20(27.8)$ \\
\hline \multirow[t]{2}{*}{ Child's place of delivery } & At home & $1(0.7)$ & $25(17.1)$ & $29(20.0)$ & $90(62.1)$ & $55(37.9)$ \\
\hline & At health institution & $4(0.7)$ & $48(8.5)$ & $95(16.9)$ & $415(73.8)$ & $147(26.2)$ \\
\hline \multirow[t]{2}{*}{ Type of child birth } & Twin & $1(6.7)$ & $4(26.7)$ & $3(20.0)$ & $7(46.7)$ & $15(53.3)$ \\
\hline & Singleton & $4(0.6)$ & $69(10.0)$ & $121(17.5)$ & $498(72.0)$ & $194(28.0)$ \\
\hline \multirow{3}{*}{$\begin{array}{l}\text { Frequency of Complementary } \\
\text { feeding }\end{array}$} & $<3$ times per day & $1(3.7)$ & $6(22.2)$ & $7(17.1)$ & $13(64.8)$ & $14(519)$ \\
\hline & 3-4 times per day & $3(0.6)$ & $54(10.0)$ & $90(16.6)$ & $394(72.8)$ & $147(27.2)$ \\
\hline & $>4$ times per day & $1(0.7)$ & $13(9.4)$ & $27(19.4)$ & $98(70.5)$ & $41(29.5)$ \\
\hline \multirow[t]{2}{*}{ Loss of appetite } & Yes & $2(1.4)$ & $15(10.7)$ & $34(24.3)$ & 89 (63.6) & $51(36.4)$ \\
\hline & No & $3(0.5)$ & $58(10.2)$ & $90(15.9)$ & $416(73.4)$ & $51(9.0)$ \\
\hline \multirow{2}{*}{$\begin{array}{l}\text { Presence of morbidity } \\
\text { symptoms }\end{array}$} & Yes & $2(1.3)$ & $16(10.5)$ & $38(25.0)$ & $96(63.2)$ & $56(36.8)$ \\
\hline & No & $3(0.5)$ & $57(10.3)$ & $86(15.5)$ & $409(73.7)$ & $146(26.3)$ \\
\hline \multirow[t]{2}{*}{ Child being breastfed } & Yes & $4(1.3)$ & $48(15.9)$ & $71(23.6)$ & $178(59.1)$ & $123(40.9)$ \\
\hline & No & $1(0.2)$ & $25(6.2)$ & $53(13.1)$ & $327(80.3)$ & 79 (19.5) \\
\hline \multirow[t]{2}{*}{ Presence of Diarrhea } & Yes & 0 & $8(9.6)$ & $23(27.1)$ & $52(62.7)$ & $31(37.3)$ \\
\hline & No & $5(0.8)$ & $65(10.4)$ & $101(62.2)$ & $453(72.6)$ & $624(27.4)$ \\
\hline \multirow[t]{3}{*}{ Preceding birth interval $^{a}$} & 12-24 months & $1(1.2)$ & $9(10.8)$ & $16(19.3)$ & $57(68.7)$ & $26(31.3)$ \\
\hline & 25-48 months & $1(0.7)$ & $19(12.8)$ & $24(16.1)$ & $105(70.5)$ & $44(29.5)$ \\
\hline & $>48$ months & $1(0.5)$ & $16(8.6)$ & $26(14.0)$ & $143(76.9)$ & $43(23.1)$ \\
\hline \multirow[t]{2}{*}{ Maternal marital status } & Married & $4(0.6)$ & $61(9.9)$ & $106(17.1)$ & $448(72.4)$ & 171 (27.6) \\
\hline & Unmarried $^{c}$ & $1(1.1)$ & 12 (13.6) & $18(20.5)$ & $57(64.8)$ & $31(35.2)$ \\
\hline
\end{tabular}


Table 3 The prevalence and severity of anemia according to selected children and parental characteristics (Continued)

\begin{tabular}{|c|c|c|c|c|c|c|}
\hline \multirow[t]{2}{*}{ Variable } & \multirow[t]{2}{*}{ Categories } & \multicolumn{5}{|c|}{ Anemic status and severity level (n (\%)) } \\
\hline & & Severely anemic & Moderately anemic & Mildly anemic & Non-anemic & $\begin{array}{l}\text { Overall anemia } \\
\text { prevalence }\end{array}$ \\
\hline \multirow[t]{2}{*}{ Pre-lacteal feeding } & Yes & 0 & $8(13.8)$ & $13(22.4)$ & $37(63.8)$ & $21(36.2)$ \\
\hline & No & $5(0.8)$ & $65(10.0)$ & $111(17.1)$ & $468(72.1)$ & $181(27.9)$ \\
\hline \multirow[t]{2}{*}{ Number of under five children } & 1 & $2(0.4)$ & $58(10.3)$ & $100(17.7)$ & $405(71.7)$ & $160(28.3)$ \\
\hline & $\geq 2$ & $3(2.1)$ & $15(10.6)$ & $24(16.9)$ & $100(70.4)$ & $42(29.6)$ \\
\hline \multirow[t]{2}{*}{ Family monthly income ${ }^{b}$} & $<108 \$$ & $4(0.9)$ & $50(11.2)$ & $88(19.7)$ & $304(68.2)$ & $142(31.8)$ \\
\hline & $\geq 108 \$$ & $1(0.4)$ & $23(8.8)$ & 36 (13.8) & 201 (77.0) & $60(23.0)$ \\
\hline
\end{tabular}

ANC antenatal care; ${ }^{a}$ Percentage was calculated for 418 children whose birth order is 2 nd and above. ${ }^{b}$ classified on the basis of the mean value; Unmarried ${ }^{c}$ : includes Single, divorced and widowed

in agreement with other studies [34, 42]. Besides, the odds of being anemic were higher for children who were in the age group of 6-23 months, which is consistent with studies done elsewhere [19, 33, 37, 39, 43]. The reasons for a high likelihood of being anemic in younger aged children may be due to different factors. The first reason would be a nutritional imbalance, as young children require relatively large nutritional demands owing to the high rate of growth during the first two years of life in combination with rapid expansion of blood volume. Since the practices and timely initiation of complementary feeding is poor in Ethiopia as evidenced by Ethiopian Demographic and Health Survey [44], younger children may suffer from at least one micronutrient deficiencies (Vitamin B12, folate, or iron) which leads to the onset of anemia. The second reason may be due to the low concentration of iron and other micronutrients in breast milk that cannot be sufficient for daily requirement of child growth [45]. Thirdly, it would also be due to the high susceptibility of young children to infectious diseases, which affects the absorption and utilization of bioavailable of micronutrients. Although our study did not include infectious diseases such as malaria and intestinal parasitic infection, they are highly prevalent in Gondar town [46, 47], and may also be a cause for red blood cell hemolysis and loss of appetites, which exacerbate the problem [48].

Consistent with previous studies [18, 22, 49], our study showed that older children were less likely to be anemic as compared to younger aged children As described in previous research [39], the $\mathrm{Hb}$ concentration had a linear and a positive association with age. The possible explanation for this may be due to the fact that with an increase in age, the nutritional demand for growth relatively becomes lower than early age. In addition, the children tend to discontinue breastfeeding and get involved in complementary feeding so that they can eat more varied diet [50]. Thus, as the children getting older, they become less likely to be anemic.
Children of mothers with primary education were two times more likely to be anemic as compared to children whose mothers attended secondary and/or above education. The finding is consistent with the literature [14, 49, 51]. This may be related to the knowledge and practices of mothers about child feeding and health care; mothers with low educational level may not have adequate knowledge regarding the appropriate child health care practices and feeding [31]. Moreover, low level of maternal education may have a negative impact on the socioeconomic status of the family, which would affect the child nutritional status and optimal childcare [3, 43].

In this study, children who had a low frequency of complementary feeding practices of less than three times per day were at a greater risk of being anemic as compared to those who had a practice of feeding five or more times per day. This is consistent with previous studies [52-54], revealing that low frequency of child complementary feeding practice increased the risk of anemia. After six months, the introduction of complementary feeding is a recommended practice to adequately support the daily nutritional requirement of children. However, the practices of timely introduction of complementary foods were reported to be poor in Ethiopia, which could contribute to the low body iron level in children and ultimately causes a higher prevalence of childhood anemia [44]. Moreover, since the iron concentration in breast milk is low, insufficient to meet the daily requirement for normal children's physiological activities as well as due to the high prevalence of maternal micronutrient deficiencies in developing countries [43], consumption of balanced complementary foods which meets the minimum dietary diversity and frequency is mandatory for children [1].

With regard to maternal marital status, children of unmarried mothers (i.e. single, widowed and divorced) were more likely to be anemic as compared to those whose mothers were married. Evidence speculated that parental marital status had an impact on family structure and 


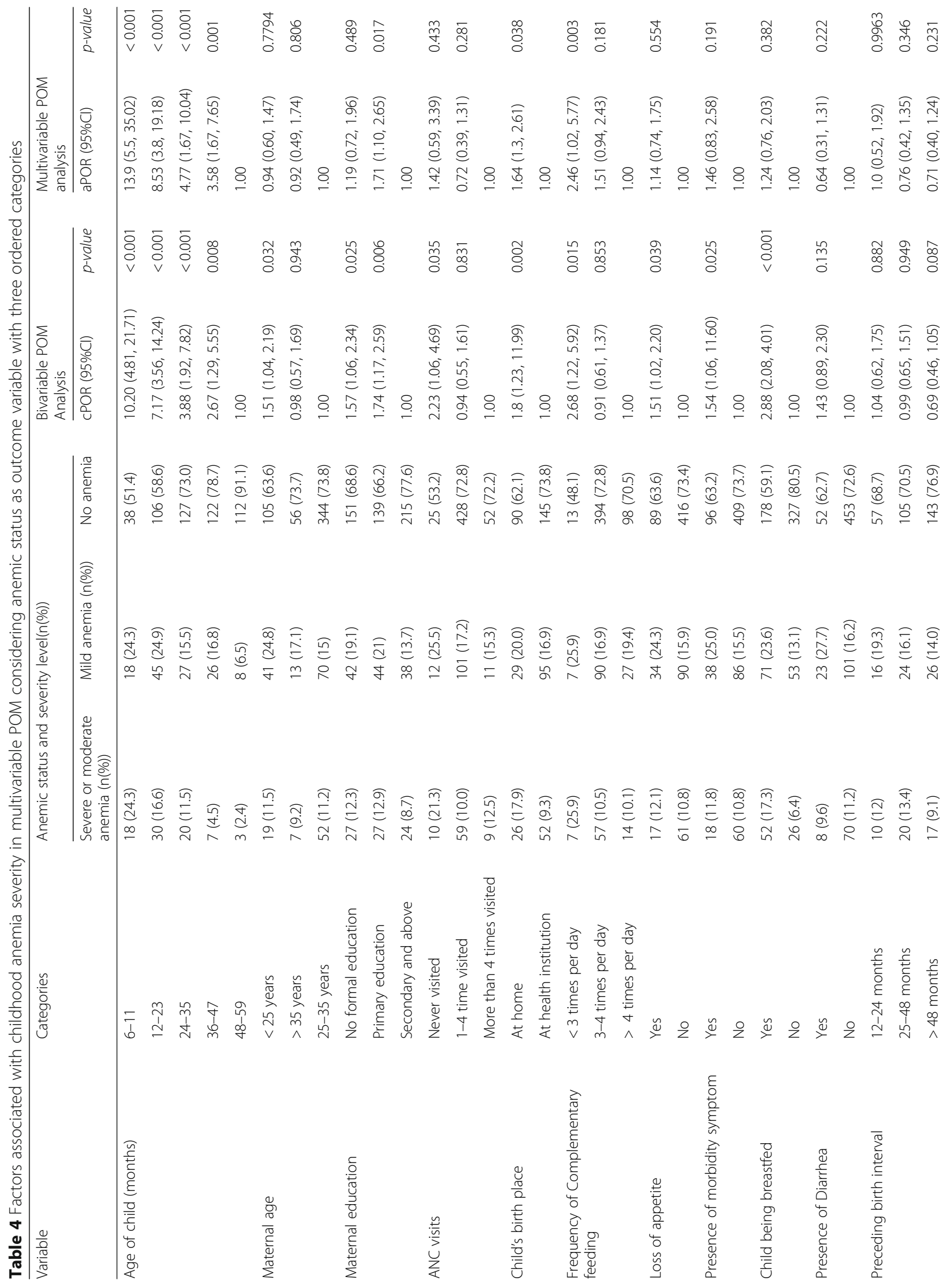


Melku et al. Italian Journal of Pediatrics (2018) 44:107

Page 9 of 12

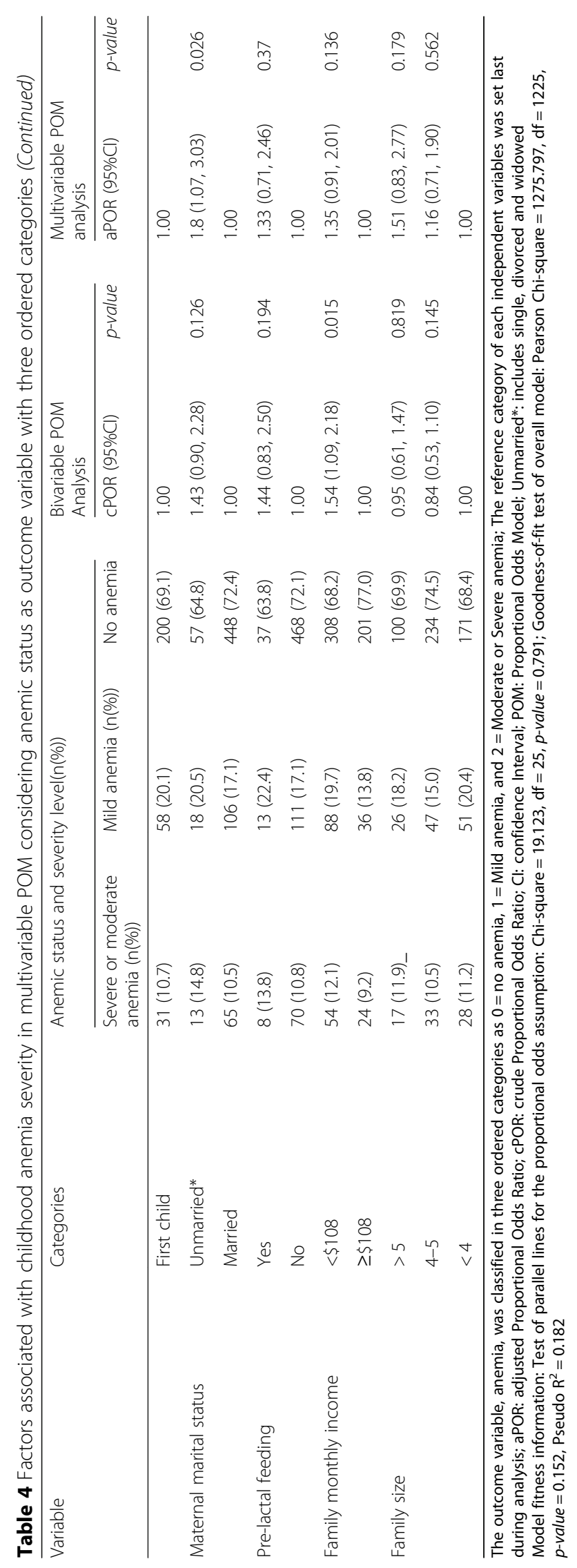


socioeconomic status $[55,56]$. The economic deprivation of unmarried mother may be partially responsible for the disadvantaged socioeconomic outcomes as well as the well-being of children. Moreover, children whose parents lack financial resources are less likely to receive high-quality of child care, health care and other social services [26]. Low socioeconomic status may, in turn, increase the risk of food insecurity, malnutrition and susceptibility to infectious diseases, which inevitably results in the development of childhood anemia [25]. Furthermore, evidence revealed that unmarried mothers experience a high rate of major depressive illness and distress [28], and they also spend less time with their children than married mothers do [57]. Therefore, low socioeconomic status and depression illness in unmarried mothers would likely influence the quality of child care that they provide for their children, and this may be the cause of childhood anemia.

In this study, a place where a child was delivered has been significantly associated with severity of childhood anemia. In children who were delivered at home, the odds of being anemic was 1.64 times higher than those children who were delivered at a health institution. Institutional delivery improves maternal health as well as healthcare practices related to infant and child care. Contrary to this, home delivery has been implicated in maternal and child morbidity and mortality. Evidence revealed that delayed breastfeeding beyond two hours and pre-lacteal feeding were high in children who were delivered at home than health institution [58]. Delayed breastfeeding initiation and pre-lactal feeding increase the risk of child morbidity $[59,60]$, and thus contribute to anemia development.

\section{Limitations}

This study has some limitations. Firstly, the cross-sectional nature of the study design does not allow to establish a cause-and-effect relationship. Secondly, this study did not include all modifiable risk factors as well as common infectious diseases that potentially deregulate the hematopoiesis such as HIV intestinal parasite, and malaria. Thirdly, we used only $\mathrm{Hb}$ value to define anemia, and serum hematinic levels were not assessed. Despite these limitations, it is the first community-based cross-sectional study, which tried to show the prevalence and associated factors of childhood anemia severity in the study area.

\section{Conclusions}

In conclusion, anemia was found to be a moderate public health problem among children aged 6-59 months in Gondar Town. The study revealed that young child age, primary maternal educational level, low frequency of child complementary feeding practices, home delivery and unmarried maternal marital status (i.e. single, divorced and widowed) were factors associated with childhood anemia severity in the study setting. Therefore, appropriate and tailored interventional strategies are required to reduce the prevalence of childhood anemia. These include improving women's access to education; providing health education on child feeding practices; and strengthening nutritional and social supports. Furthermore, further in-depth studies need to be conducted using a large sample size and including assessment of serum micronutrient level.

\section{Abbreviations \\ ANC: Antenatal care; aPOR: adjusted Proportional Odds Ratio; BMI: Body Mass Index; Cl: Confidence Interval; CPOR: crude Proportional Odds Ratio; \\ CS: Caesarian Section; HAZ: Z-score for Height-for-Age; Hb: Hemoglobin; IQR: Interquartile Range; MDG: Millennium Development Goals; \\ POM: Proportional Odds Model; SD: Standard Deviation; USD: US Dollar; \\ WAZ: Z-scores for Weight-for-Age; WHO: World Health Organization; WHZ: \\ Z-score for Weight-for-Height}

\section{Acknowledgements}

The authors would like to thank all children and their families who voluntarily participated in the study. We are also grateful to thank data collectors, Gondar Town Health Department and the University of Gondar for their logistics and material support.

\section{Funding}

The authors received no specific funding for this work.

\section{Availability of data and materials}

All data supporting the findings and conclusion are presented in the manuscript. The datasets during and/or analyzed during the current study is available from the corresponding author on reasonable request.

\section{Authors' contributions}

Conceived and designed the experiments: MM. Helped in designing the study and participated in data collection: MM, KAA, TM, BE, BT, TM, AK, BB, MA. Supervised the data collection process: MM, TM, AK. Involved in data entry: MM, TM. Analyzed and interpreted the data: MM, KFM. Contributed reagents/materials/equipments: KAA, MA. Drafted the manuscript: MM. Critically edited and revised the manuscript. All authors read and approved the final manuscript.

\section{Ethics approval and consent to participate}

Ethical clearance was obtained from the Institutional Review Board of the University of Gondar (No: RPC/46/2014). Permission was sought from Gondar City Health Department. Written consent was obtained from each parent after the purpose and importance of the study were explained to them. The signed informed consent was kept confidentially, and the data were analyzed anonymously according to the Declaration of Helsinki for human studies. Nutritional and health advice were given to each parent at the end of the interview. Anemic children were referred to nearby health facilities to get standard treatment for anemia.

\section{Consent for publication}

Not applicable.

\section{Competing interests}

The authors declare that they have no competing interests.

\section{Publisher's Note}

Springer Nature remains neutral with regard to jurisdictional claims in published maps and institutional affiliations.

\section{Author details}

'Department of Hematology and Immunohematology, School of Biomedical and Laboratory Sciences, College of Medicine and Health Sciences, University of Gondar, Gondar, Ethiopia. ${ }^{2}$ Department of Epidemiology and Biostatistics, Institute of Public Health, College of Medicine and Health Sciences, 
University of Gondar, Gondar, Ethiopia. ${ }^{3}$ Department of Clinical Chemistry, School of Biomedical and Laboratory Sciences, College of Medicine and Health Sciences, University of Gondar, Gondar, Ethiopia. ${ }^{4}$ School of Nursing, College of Medicine and Health Sciences, University of Gondar, Gondar, Ethiopia. ${ }^{5}$ School of Medicine, College of Medicine and Health Sciences, University of Gondar, Gondar, Ethiopia.

\section{Received: 2 May 2018 Accepted: 26 August 2018}

\section{Published online: 03 September 2018}

\section{References}

1. McLean E, Cogswell M, Egli I, Wojdyla D, De Benoist B. Worldwide prevalence of anaemia, WHO vitamin and mineral nutrition information system, 1993-2005. Public Health Nutr. 2009;12(4):444-54.

2. Steel N. Global, regional, and national age-sex specific mortality for 264 causes of death, 1980-2016: a systematic analysis for the global burden of disease study 2016. Lancet. 2017;390(10100):1151-210.

3. Central Statistical Agency. Ethiopia Demographic and Health Survey 2011. Addis Ababa, Ethiopia; 2012. Available at: https://dhsprogram.com/pubs/ pdf/FR255/FR255.pdf. Accessed date: 18/10/2017.

4. Gessner BD. Early childhood hemoglobin level is a strong predictor of hemoglobin levels during later childhood among low-income Alaska children. Int J Circumpolar Health. 2009;68(5):459-70.

5. Chen MH, Su TP, Chen YS, Hsu JW, Huang KL, Chang WH, et al. Association between psychiatric disorders and iron deficiency anemia among children and adolescents: a nationwide population-based study. BMC Psychiatry. 2013;13:161

6. Chang S, Wang L, Wang Y, Brouwer ID, Kok FJ, Lozoff B, et al. Iron-deficiency Anemia in infancy and social emotional development in preschool-aged Chinese children. Pediatrics. 2011;127(4):e927-e33.

7. Carter RC, Jacobson JL, Burden MJ, Armony-Sivan R, Dodge NC, Angelilli ML, et al. Iron deficiency Anemia and cognitive function in infancy. Pediatrics. 2010;126(2):e427-e34.

8. Lozoff B, Beard J, Connor J, Felt B, Georgieff M, Schallert T. Long-lasting neural and behavioral effects of Iron deficiency in infancy. Nutr Rev. 2006; 64(Suppl 2):S34-43.

9. Grantham-McGregor S, Ani C. A review of studies on the effects of iron deficiency on cognitive development. J Nutr. 2001;131(2):649S-68S.

10. Trivedi M, Chansoria A, Dixit RK, Kholi A. Evaluation of brief cognitive rating scale of anemic patients and comparison with control. Int J of Res in Pharm Sci. 2012;2(4):89-95.

11. Halterman JS, Kaczorowski JM, Aligne CA, Auinger P, PG S. Iron deficiency and cognitive achievement among school-aged children and adolescents in the United States. Pediatrics. 2001:107(6):1381-6.

12. Phiri KS, Calis JC, Faragher B, Nkhoma E, Ng'oma K, Mangochi B, et al. Long term outcome of severe Anaemia in Malawian children. PLoS One. 2008; 3(8):e2903.

13. Ehrhardt S, Burchard GD, Mantel C, Cramer JP, Kaiser S, Kubo M, et al. Malaria, anemia, and malnutrition in african children--defining intervention priorities. J Infect Dis. 2006;194(1):108-14.

14. Singh RK, Patra S. Anemia. Extent of Anaemia among preschool children in EAG states. India: A Challenge to Policy Makers. Volume; 2014.

15. Soares Magalha”es RJ, ACA C. Mapping the Risk of Anaemia in PreschoolAge Children: The Contribution of Malnutrition, Malaria, and Helminth Infections in West Africa. PLoS Med. 2011;8(6):e1000438.

16. Wirth JP, Rohner F, Woodruff BA, Chiwile F, Yankson H, Koroma AS, et al. Anemia, micronutrient deficiencies, and malaria in children and women in Sierra Leone prior to the Ebola outbreak - findings of a cross-sectional study. PLoS One. 2016;11(5):e0155031.

17. Semba RD, de Pee S, Ricks MO, Sari M, Bloem MW. Diarrhea and fever as risk factors for anemia among children under age five living in urban slum areas of Indonesia. Int J Infect Dis. 2008;12(1):62-70.

18. Agho KE, Dibley MJ, D'Este C, Gibberd R. Factors associated with Haemoglobin concentration among Timor-Leste children aged 6-59 months. J Health Popul Nutr. 2008;26(2):200-9.

19. Cardoso MA, Scopel KKG, Muniz PT, Villamor E, Ferreira MU. Underlying factors associated with Anemia in mazonian children: a population-based, Cross-Sectional Study. PLoS ONE. 2012;7(5):e36341.

20. Sinha N, Deshmukh PR, Garg BS. Epidemiological correlates of nutritional anemia among children (6 -35 months) in rural Wardha, Central India. Indian J Med Sci. 2008;62(2):45.
21. Jaime-Perez JC, Herrera-Garza JL, Gomez-Almaguer D. Relationship between gestational iron deficiency and iron deficiency in the newborn; erythrocytes. Hematology. 1999;5(3):257-62.

22. Pasricha SR, Black J, Muthayya S, Shet A, Bhat V, Nagaraj S, et al. Determinants of Anemia among young children in rural India. Pediatrics. 2010;126(1):140-e9.

23. Suchdev PS, Ruth $L$, Earley M, Macharia A, Williams TN. The burden and consequences of inherited blood disorders among young children in western Kenya. Matern Child Nutr. 2014;10:135-44.

24. WHO multicentre growth reference study group. WHO child growth standards based on length/height, weight and age. Acta Pædiatrica. 2006; 450:76-85.

25. Skalicky A, Meyers AF, Adams WG, Yang Z, Cook JT, Frank DA. Child food insecurity and iron deficiency anemia in low-income infants and toddlers in the United States. Matern Child Health J. 2006:10(2):177-85.

26. McLanahan S, Percheski C. Family structure and the reproduction of inequalities. Annu Rev Sociol. 2008:34:257-76.

27. Patel AJ, Wesley R, Leitman SFBB. Capillary versus venous haemoglobin determination in the assessment of healthy blood donors. Vox Sang. 2013; 104:317-23.

28. Avison WR, Davies L. Family structure, gender, and health in the context of the life course. J Gerontol B Psychol Sci Soc Sci. 2005;60(Special Issue): S113-S6.

29. WHO. WHO STEPS surveillance manual : the WHO STEPwise approach to chronic disease risk factor surveillance / Noncommunicable Diseases and Mental Health. Geneva: WHO; 2005. Available at: http://apps.who.int/iris/ bitstream/10665/43376/1/9241593830_eng.pdf. Accessed date: 10/1/2014

30. Gari T, Loha E, Deressa W, Solomon T, Atsbeha H, Assegid M, et al. Anaemia among children in a drought affected community in south-Central Ethiopia. PLoS One. 2017;12(3):e0170898.

31. Leal LP, Batista Filho M, Lira PI, Figueiroa JN, Osório MM. Prevalence of anemia and associated factors in children aged 6-59 months in Pernambuco, Northeastern Brazil. Rev Saude Publica. 2011;45(3):457-66.

32. Habte D, Asrat K, Magafu MG, Ali IM, Benti T, Abtew W, et al. Maternal risk factors for childhood Anaemia in Ethiopia. Afr J Reprod Health. 2013;17(3):110-8.

33. Gebreegziabiher G, Etana B, Niggusie D. Determinants of Anemia among children aged 6-59 months living in Kilte Awulaelo Woreda. Volume: Northern Ethiopia. Anemia; 2014

34. Muchie KF. Determinants of severity levels of anemia among children aged 6-59 months in Ethiopia: further analysis of the 2011 Ethiopian demographic and health survey. BMC Nutr. 2016;2:51.

35. Schellenberg D, Schellenberg JR, Mushi A, Savigny DD, Mgalula L, Mbuya C, et al. The silent burden of anaemia in Tanzanian children: a communitybased study. Bull World Health Organ. 2003:81(8):581-90.

36. Ngnie-Teta I, Receveur O, Kuate-Defo B. Risk factors for moderate to severe anemia among children in Benin and Mali: insights from a multilevel analysis. Food Nutr Bull. 2007;28(1):76-89.

37. Ag Ayoya M, Ngnie-Teta I, Séraphin MN, Mamadoultaibou A, Boldon E, Saint-Fleur JE, et al. Prevalence and risk factors of Anemia among children 6-59 months old in Haiti. Volume: Anemia; 2013.

38. Uddin MK, Sardar MH, Hossain MZ, Alam MM, Bhuya MF, Uddin MM, et al. Prevalence of anaemia in children of 6 months to 59 months in Narayanganj, Bangladesh. J Dhaka Med Coll. 2010;19(2):126-30.

39. Oso'rio MM, Lira Pl, Ashworth A. Factors associated with $\mathrm{Hb}$ concentration in children aged 6-59 months in the state of Pernambuco. Brazil Br J Nutr. 2004;91(2):307-14

40. Saraiva BC, Soares MC, Santos LC, Pereira SC, Horta PM. Iron deficiency and anemia are associated with low retinol levels in children aged 1 to 5 years. J Pediatr. 2014;90(6):593-9.

41. Gao W, Yan H, DuolaoWang DS, Pei L. Severity of Anemia among Children under 36 Months Old in Rural Western China. PLoS ONE. 2013;8(4):e62883.

42. Khanal V, Karkee R, Adhikari M, Gavidia T. Moderate-to-severe anaemia among children aged 6-59 months in Nepal: an analysis from Nepal demographic and health survey, 2011. Clin Epidemiol Glob Health. 2016;4:57-62.

43. Khan JR, Awan N, Misu F. Determinants of anemia among 6-59 months aged children in Bangladesh: evidence from nationally representative data. BMC Pediatr. 2016;16:3.

44. Disha A, Tharaney M, Abebe Y, Alayon S, Winnard K. Factors associated with infant and young child feeding practices in Amhara region and nationally in Ethiopia: analysis of the 2005 and 2011 demographic and health surveys. Washington, DC: Alive and Thrive; 2015. 
45. Ewusie JE, Ahiadeke C, Beyene J, Hamid JS. Prevalence of anemia among under-5 children in the Ghanaian population: estimates from the Ghana demographic and health survey. BMC Public Health. 2014;14:626.

46. Tilaye T, Deressa W. Prevalence of urban malaria and assocated factors in Gondar town, Northwest Ethiopia. Ethiop Med j. 2007;45(2):151-8.

47. Gelaw A, Anagaw B, Nigussie B, Silesh B, Yirga A, Alem M, et al. Prevalence of intestinal parasitic infections and risk factors among school children at the University of Gondar Community School, Northwest Ethiopia: a cross-sectional study. BMC public health. 2013;13:304.

48. Zanin FHC, da Silva CAM, Bonomo É, Teixeira RA, CAdJ P, dos Santos KB, et al. Determinants of Iron Deficiency Anemia in a Cohort of Children Aged 6-71 Months Living in the Northeast of Minas Gerais, Brazil. PLoS ONE. 2015;10(10):e0139555.

49. Leite MS, Cardoso AM, Coimbra CEA Jr, Welch JR, Gugelmin SA, Lira PCl, et al. Prevalence of anemia and associated factors among indigenous children in Brazil: results from the first National Survey of indigenous People's health and nutrition. Nutr J. 2013;12:69.

50. El Kishawi RR, Soo KL, Abed YA, Wan Muda WAM. Anemia among children aged 2-5 years in the Gaza strip- Palestinian: a cross sectional study. BMC Public Health. 2015;15:319.

51. Yang W, Li X, Li Y, Zhang S, Liu L, Wang X, et al. Anemia, malnutrition and their correlations with socio-demographic characteristics and feeding practices among infants aged $0-18$ months in rural areas of Shaanxi province in northwestern China: a cross-sectional study. BMC Public Health. 2012;12:127.

52. Hipgrave DB, Fu X, Zhou H, Jin Y, Wang X, Chang S, et al. Poor complementary feeding practices and high anaemia prevalence among infants and young children in rural central and western China. Eur J Clin Nutr. 2014;68(8):916-24.

53. Hu S, Tan H, Peng A, Jiang H, Wu J, Guo S, et al. Disparity of anemia prevalence and associated factors among rural to urban migrant and the local children under two years old: a population based cross-sectional study in Pinghu, China. BMC Public Health. 2014;14:601.

54. Roba KT, O'Connor TP, Belachew T, O'Brien NM. Anemia and undernutrition among children aged 6-23 months in two agroecological zones of rural Ethiopia. Pediatr Health Med Ther. 2016;7:131-40.

55. Hannan C, Halpin B. The Influence of Family Structure on Child Outcomes: Evidence for Ireland. Econ Soc Rev. 2014;45(1, Spring):1-24.

56. Manning WD, Brown S. Children's economic well-being in marriage and cohabiting parent families. J Marriage Fam. 2006;68(2):345-62.

57. Kendig SM, Bianchi SM. Single, cohabiting, and married mothers' time with children. J Marriage Fam. 2008;70(5):1228-40,

58. Jain A, Baliga BS, Rao S, Shankar MV, Srikanth BK. Does institutional delivery help in improving infant and child health care practices and health promotion related parameters? A study from Bellary, Karnataka. BMC Proceedings. 2012;6(Suppl 5):O22.

59. Edmond KM, Zandoh C, Quigley MA, Amenga-Etego S, Owusu-Agyei S, Kirkwood BR. Delayed breastfeeding initiation increases risk of neonatal mortality. Pediatrics. 2006;117(3):e380-6.

60. Hajeebhoy N, Nguyen PH, Mannava P, Nguyen TT, Mai LT. Suboptimal breastfeeding practices are associated with infant illness in Vietnam. Int Breastfeed J. 2014;9:12

Ready to submit your research? Choose BMC and benefit from:

- fast, convenient online submission

- thorough peer review by experienced researchers in your field

- rapid publication on acceptance

- support for research data, including large and complex data types

- gold Open Access which fosters wider collaboration and increased citations

- maximum visibility for your research: over $100 \mathrm{M}$ website views per year

At BMC, research is always in progress.

Learn more biomedcentral.com/submissions 